\title{
X. On a phœnomenon in which the distant objects were seen inverted
}

\section{Edward Joseph Lowe Esq.}

To cite this article: Edward Joseph Lowe Esq. (1845) X. On a phœnomenon in which the distant objects were seen inverted, Philosophical Magazine Series 3, 27:177, 41-41, DOI: $10.1080 / 14786444508645222$

To link to this article: http://dx.doi.org/10.1080/14786444508645222

册 Published online: 30 Apr 2009.

Submit your article to this journal $\sqsubset \pi$

Џ Article views: 2

Q View related articles $\asymp$ 
X. On a Phrenomenon in rohich the distant objects were seen inverted. By EDward Joseph Lowe, Esq.*

$\mathrm{N}$ Thursday, April 17, 1845, at $2^{\mathrm{h}} 20^{\mathrm{m}}$ p.m., a curious and very unusual phænomenon was observed near Radford, which is situated about a mile W. of Nottingham.

A group of trees at the distance of two miles, and a hill (behind the trees) at the distance of four miles at the most remote portion from the place of observation, were seen inverted in the air and of a gray colour; the inverted phænomenon did not touch the objects of which they were the image, but appeared about $30^{\prime}$ elevated above them. There was a haze between the objects and the phænomenon; also the summits of the inverted landscape did not end in blue sky, but were observed also to end in haze. The breadth of the hill was $20^{\circ}$, which was inverted of an equal size, and appeared somewhat to resemble Pendle Hill in Lancashire. The phænomenon was seen for five minutes, and when left still visible; returning an hour afterwards it had vanished. No clouds were visible at the time, and the wind was very brisk.

The morning had been cloudless until $10^{\mathrm{h}}$ a.m., then few cumuli clouds of small size floated over, increasing in abundance until $1^{\mathrm{h}}$ p.m., when they began to disappear below the S.E. horizon; at $2^{\mathrm{h}}$ p.m. sky almost cloudless and the weather warm, soon after perfectly cloudless; at $3^{\mathrm{h}}$ p.m. cirrostrati formed themselves on N.W. horizon ; these increased rapidly, and in an hour covered the sky, which remained overcast for the rest of the day. The barometer fell from 30.596 in. at $9^{\mathrm{h}}$ a.m. to 30.560 in. at $9^{\mathrm{h}}$ p.m. (attached thermometer $9^{\mathrm{h}}$ a.m., $64^{\circ} ; 9^{\mathrm{h}}$ p.m., $66^{\circ}$ ); the minimum temperature was $36^{\circ}$, and the maximum temperature $58^{\circ} .7$; the direction of the wind and clouds was from the N.E., and the distant prospect rather hazy. There is a valley of some considerable size in the direction of the phænomenon, but not much water; the principal portion is the river Leen, which is about seven yards wide, and does in some measure take its course in a direction from the observer to the phænomenon.

XI. On a Magnificent Meteor seen in Nottinghamshire. By Edward Joseph Lowe, Esq.*

$\mathrm{O}^{\mathrm{N}}$ Thursday, April 24, 1845, a blue meteor, of a most unusual size and brilliancy, was seen near High Field House (lat. $52^{\circ} 57^{\prime} 30^{\prime \prime}$; long. $1^{\circ} 11^{\prime}$ W.) in the above county.

The weather had been for the five days prior to the 24th hot, and almost cloudless; for the mean of clouds for that

* Communicated by the Author. 